\title{
Drosera ANGLiCA In Alaska
}

MIKE BALDWIN • Anchorage, Alaska・USA・mike@carnivorousplants.org

For years I have been interested in the native carnivorous plants of Alaska. In particular the sundews have held my continued fascination. I grew up with my grandmother's stories of "purple people eater" sightings-her name for sundews that grew in the bogs around our family cabin on the Kenai Peninsula.

Little has been written about carnivorous plants in Alaska. Typically the literature has been limited to brief descriptions found in flora guidebooks (Pratt 1991, 1993; Schaffer 2000), or a brief description of species and range (Hulten 1968; Schnell 2002). There are two sundews native to Alaska, Drosera rotundifolia and D. anglica. D. rotundifolia has been recorded from all across Alaska, while the literature on the distribution of D. anglica hasn't been quite as clearly defined. Schnell's (2002) range map shows a narrow distribution of D. anglica in Alaska limited to Kodiak Island in Southcentral Alaska. It is shown in neighboring British Columbia, so it is conceivable that it could be in Southeast Alaska as well. Hulten (1968) showed a greater distribution of locations across the state.

It is not surprising that there are differences in published ranges, with additional sites beyond what is typically shown. Alaska is a large state. The road system is very limited in Alaska, and much of Alaska can only be easily reached by small plane or boat during a brief summer growing season. As a result, many parts of the state are botanically under explored.

Over the past several years I have explored a number of bogs in Southcentral Alaska and have found D. rotundifolia galore! However, until recently, I have been unsuccessful in finding D. anglica. To help narrow my search for this little beauty, I searched the University of Alaska Museum of the North Herbarium (ALA) for any specific locality data. A search of the herbarium data base (accessed 7 January 2013) listed 79 records for D. anglica in Alaska, of which 64 had specific local-

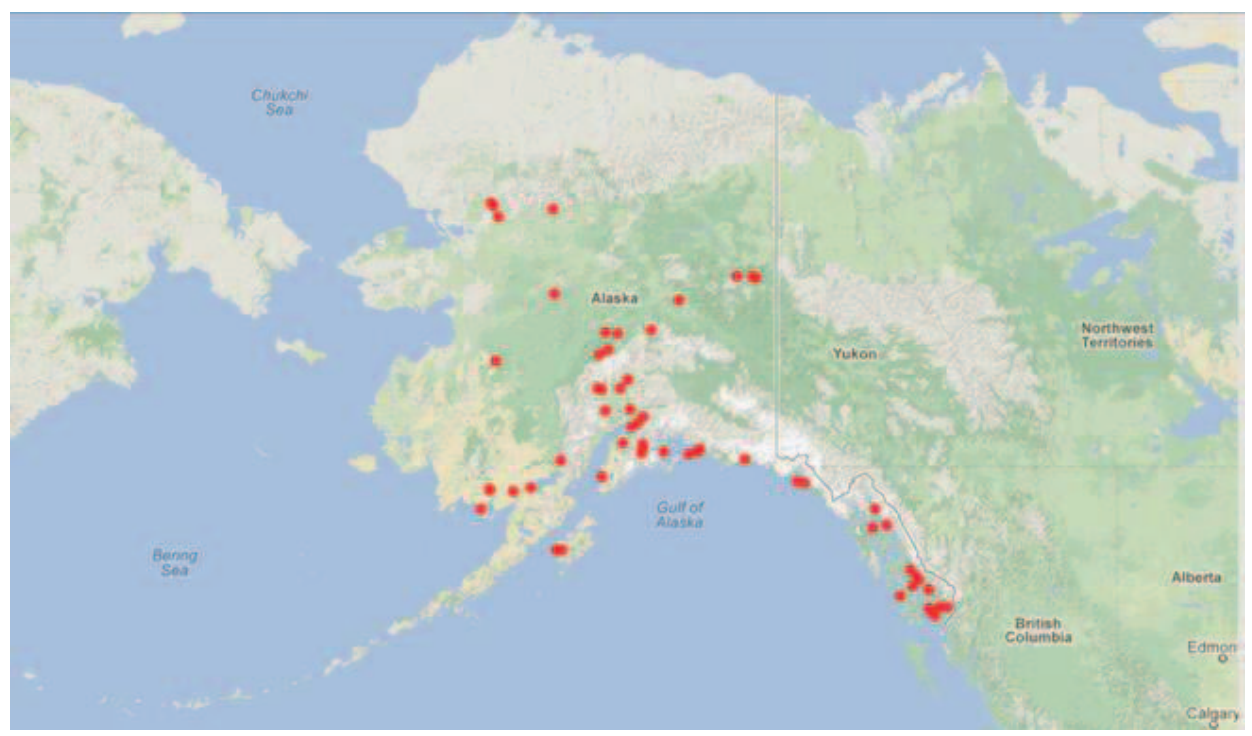

Figure 1: Distribution of Drosera anglica in Alaska based on specimen data in the University of Alaska Museum of the North Herbarium (ALA). Map generated from herbarium data by Berkeley Mapper using Google Maps. 
ity data. As can be seen from Fig. 1, D. anglica is broadly distributed in Alaska. As more remote locations are explored, I have great confidence in further range extension.

The herbarium data helped confirm that historically there have been populations of $D$. anglica on the Kenai Peninsula where I tend to spend time bog hopping looking for carnivorous plants. Encouraged by this, my efforts were rewarded this past summer on a bog hopping field trip where I finally found a healthy population of $D$. anglica!

\section{References}

Hulten, E. 1968. Flora of Alaska and Neighboring Territories: A Manual of the Vascular Plants. Stanford University Press.

Pratt, V. 1991. Wildflowers along the Alaska Highway. Alaskacrafts Inc.

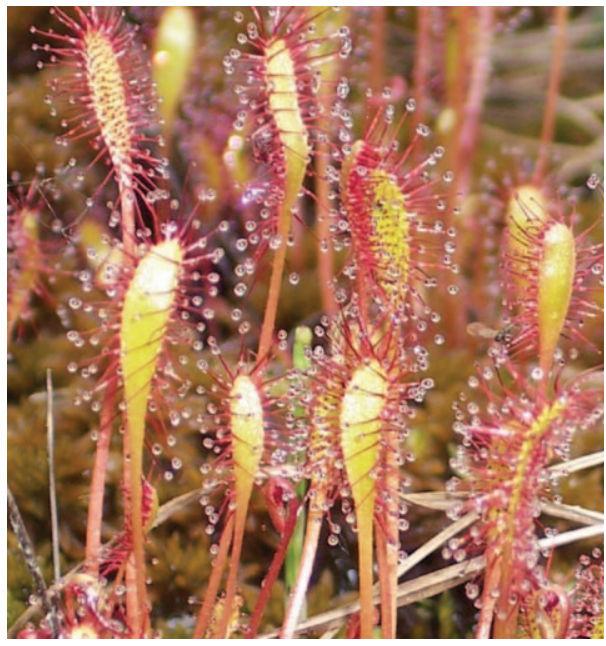

Figure 2: Drosera anglica from a Kenai Peninsula bog during the summer of 2012. Photograph by Mike Baldwin.

Pratt, V. 1993. Wildflowers of Denali National Park. Alaskacrafts Inc.

Schaffer, B. 2000. The Flora of South Central Alaska, 3rd Edition. Kenai Peninsula College, Arts $\&$ Sciences Division.

Schnell, D.E. 2002. Carnivorous Plants of the United States and Canada, 2nd Edition. Timber Press. University of Alaska Museum of the North Herbarium. http://www.uaf.edu/museum/collections/ herb/, ALA; accessed 7 January 2013.

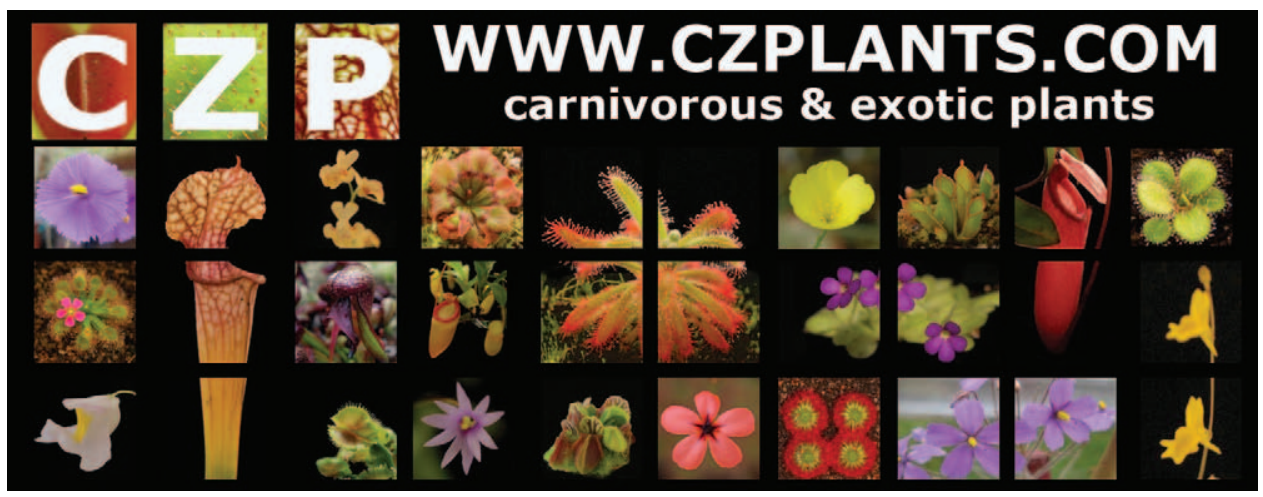

